\title{
INHERITANCE OF RESISTANCE TO Fusarium oxysporum f. sp. phaseoli BRAZILIAN RACE 2 IN COMMON BEAN
}

\author{
Mônica Juliani Zavaglia Pereira ${ }^{1}$; Magno Antonio Patto Ramalho*; Ângela de Fátima Barbosa \\ $\mathrm{Abreu}^{2,3}$ \\ Embrapa Soja - Campo Experimental de Balsas, C.P. 131 - R. da Cohab, 813 - 65800-000 - Balsas, MA - Brasil. \\ ${ }_{3}^{2} U F L A$ - Depto. de Biologia, C.P. 3037 - 37200-000 - Lavras, MG - Brasil. \\ ${ }^{3}$ Embrapa Arroz e Feijão, C.P. 179 - Rod. GO-462, km 12 - 75375-000 - Santo Antônio de Goiás, GO - Brasil. \\ *Corresponding author <magnoapr@ufla.br>
}

\begin{abstract}
Aiming to obtain information concerning the genetic control of the resistance of the bean (Phaseolus vulgaris L.) to the fungus Fusarium oxysporum f. sp. phaseoli, six crosses involving three resistant lines (Carioca MG, Esal 583 and Esal 566) and four susceptible to the fungus (Carioca, CNFC 10443, Uirapuru and Esal 522) were developed. The parental lines, the controls (Carioca MG and Carioca) and the $\mathrm{F}_{1}, \mathrm{~F}_{2}$ and $\mathrm{F}_{3}$ generations were evaluated for reaction to Fusarium. For inoculation, root cuttings were immersed in a spore suspension. The evaluations were performed at 21 days after inoculation, by scale of notes ranging from 1.0, to 9.0 and genetic and phenotypic parameters were estimated. The heritability in the narrow sense ranged from 0.34 to 0.42 and in the broad sense of 0.76 to 0.97 , showing that selection should be easy, since efficient inoculation and selection methods are used. The average degree of dominance was around 1.0 indicating the presence of dominance in the control of the character, although additive effects are also expressive.
\end{abstract}

Key words: Phaseolus vulgaris, Fusarium wild, disease resistance

\section{CONTROLE GENÉTICO DA RESISTÊNCIA À RAÇA BRASILEIRA2 DE Fusarium oxysporum f. sp. phaseoli NO FEIJOEIRO}

\begin{abstract}
RESUMO: Com o objetivo de obter informações a respeito do controle genético da resistência do feijoeiro (Phaseolus vulgaris L.) ao fungo Fusarium oxysporum f. sp. phaseoli, foram realizados seis cruzamentos envolvendo três linhagens resistentes (Carioca MG, ESAL 583 e ESAL 566) e quatro suscetíveis ao fungo (Carioca, CNFC 10443, Uirapuru e ESAL 522). As plantas dos genitores, das testemunhas (Carioca $\mathrm{MG}$ e Carioca) e das gerações $\mathrm{F}_{1}, \mathrm{~F}_{2}$ e $\mathrm{F}_{3}$ foram avaliadas quanto à reação à murcha-de-fusarium utilizando a metodologia de inoculaçã̃o de imersão de raízes na suspensão de esporos, com o corte do sistema radicular. As avaliações foram realizadas aos 21 dias após a inoculação, por meio de escala de notas variando de 1,0 (plantas sem sintomas) a 9,0 (plantas mortas). Com os dados obtidos, foram estimados parâmetros genéticos e fenotípicos. A herdabilidade no sentido restrito variou de 0,34 a 0,42 e no sentido amplo de 0,76 a 0,97 , podendo considerar o caráter como de fácil seleção, desde que se adotem critérios eficientes de inoculação e avaliação das plantas. O grau médio de dominância foi próximo de 1,0 evidenciando a presença de dominância no controle do caráter, embora a presença de efeitos aditivos também seja expressiva.

Palavras-chave: Phaseolus vulgaris, murcha de Fusarium, resistência à doenças
\end{abstract}

\section{INTRODUCTION}

Fusarium wilt, caused by the fungus Fusarium oxysporum f. sp. phaseoli Kendrick \& Snyder, is a serious vascular disease of common bean (Phaseolus vugaris L.) in Latin America, in Africa and in the northwestern United States (Buruchara \& Camacho, 2000). In Brazil, this disease has attracted special interest in the last years, due to a higher degree of mechanization in the fields, successive plantings and more than one common bean harvest per year. This disease causes vascular wilt, due to vessel colonization. The main re- flex symptom is the progressive yellowing from the lower towards the upper leaves.

Information on the number of pathogen races and the variability within races is limited. Seven pathogen races, well-distributed across the continents, are documented in the literature. In Brazil, there are indications of the predominance of one race, designated race 2 (Alves-Santos et al., 2002).

The existence of variability in the reaction to this pathogen was reported at several occasions (Salgado \& Schwartz, 1993; Woo et al., 1996; Sala et al., 2006; Pereira et al., 2008). There are some reports of ge- 
netic control of resistance; the first was probably the study of Ribeiro \& Hagedorn (1979), who identified the presence of only one gene with a dominant allele conferring resistance. More recently, other results were reported for the genetic control of resistance (Salgado et al., 1995; Cross et al., 2000; Brick et al., 2004). No report was found on the genetic control of resistance to this pathogen using exclusively germplasm developed in Brazil, nor any information about the use of the estimated mean and variance components to study this trait.

Thus, this study was conducted with the objective to obtain information on the genetic control of resistance to race 2 of Fusarium oxysporum f. sp. phaseoli.

\section{MATERIALAND METHODS}

The experiments were conducted in an experimental area located in Lavras, State of Minas Gerais, Brazil. Seven common bean lines previously evaluated for the reaction to Fusarium oxysporum f. sp. phaseoli (Pereira et al., 2008) were chosen for the crosses. The group of resistant lines were Carioca MG, Esal 566 and Esal 583 and the group of susceptible lines were Carioca, Uirapuru, CNFC 10443 and Esal 522, all with carioca grain type, with exception of Uirapuru, with black grain.

In February 2006, the lines were sown in a greenhouse. The following crosses between the resistant and susceptible lines were performed: Carioca $\mathrm{MG} \times \mathrm{Ca}-$ rioca, Carioca MG $\times$ CNFC 10443, Carioca MG $\times$ Uirapuru, ESAL $583 \times$ CNFC 10443, ESAL $583 \times$ Uirapuru and ESAL $566 \times$ ESAL 522 . Crosses between two resistant (ESAL $583 \times$ ESAL 566) and two susceptible lines (Uirapuru $\times$ ESAL 522) were performed as well.

$F_{1}$ seeds were sown in the field in August 2006 to obtain the $\mathrm{F}_{2}$ generation. The $\mathrm{F}_{2}$ seeds and of the parental lines were sown again in December 2006 to obtain the $\mathrm{F}_{3}$ generation and for maintenance of the parental lines. Part of the $F_{1}$ seeds were stored for use in later evaluations.

Five plants of the parents and of the controls (Carioca, susceptible and Carioca MG, resistant), 10 - 16 plants of the $F_{1}, 100$ plants of the $F_{2}$ and 200 plants of the $F_{3}$ generation were evaluated. The methodology of root immersion in spore suspension was used for inoculations of cuttings of the root system (PastorCorrales \& Abawi, 1987). Sowing was performed in styrofoam trays with 128 cells filled with a horticultural substrate $\left(\right.$ Plantmax $\left.^{\circledR}\right)$ that were placed in a greenhouse for plant germination and growth.

We used an isolated from the pathogen, collected in the cultivar Carioca in the 2005/2006 season. After isolating the pathogen was maintained in BOD, with temperature of $24 \pm 1^{\circ} \mathrm{C}$, under continuous lighting. To promote the sporulation, the conservation of the fungus was held in the test tube containing culture medium BDA, immersed in mineral oil. The suspension of spores was prepared minutes before each inoculation.

The plants were inoculated 9-10 days after sowing (first pair of unifoliolate leaves fully expanded). For this purpose, the plants were removed from the trays, the root system carefully washed in tap water and 1/ 3 of its length cut off with a pair of scissors and immersed in the spore suspension $\left(10^{6}\right.$ conidia $\left.\mathrm{mL}^{-1}\right)$ for five minutes. Roots of the control plants were immersed in distilled water and then transplanted to pots containing substrate. During the evaluations the pots were kept in a climate chamber at $22^{\circ} \mathrm{C} \pm 2{ }^{\circ} \mathrm{C}$, with a photoperiod of 12 hours. The plants were watered every two days and fertilized with $1.0 \mathrm{~g}$ NPK fertilizer (8-28-16), ten days after inoculation.

In all experiments, the plants were evaluated 21 days after inoculation (DAI), based on the disease severity index developed by the CIAT (Pastor-Corrales \& Abawi, 1987), in which: 1 = no leaf or vascular symptom, $3=1 \%$ to $10 \%$ of symptomatic leaves, slight wilting of plants and vascular hypocotyl discoloration, $5=11 \%$ to $25 \%$ symptomatic leaves, moderate plant wilting and vascular discoloration up to the first node, $7=26 \%$ to $50 \%$ of symptomatic leaves, severe plant wilting and vascular discoloration on the entire stem and petiole; $9=$ dead plant. Lines with mean scores between 1.0 and 3.0 were considered resistant, between 3.1 and 6.0 moderate and between 6.1 and 9.0 susceptible (Pastor-Corrales \& Abawi, 1987; Salgado \& Schwartz, 1993; Elena \& Papas, 2002).

The analyses consisted in (i) estimating the mean component, based on the model without epistasis, using a procedure similar to that proposed by Cruz et al. (2004) and in (ii) estimating the components of variance for the crosses where the $\mathrm{F}_{3}$ generation was available using the method of the iterative weighted least squares, according to Cruz et al. (2004). The estimates were obtained using software Mapgen (Ferreira \& Zambalde, 1997).

\section{RESULTS AND DISCUSSION}

The parents used confirmed the resistance or susceptibility reaction detected in previous evaluations (Pereira et al., 2008). The reactions of the two control lines were also confirmed in all experiments evaluated.

The model used to estimate the mean components, containing only $m$ (average of the contribution of the homozygous loci), $a$ (the algebraic sum of the effects 
of the homozygous loci measured as deviations from the mean, additive effect) and $d$ (deviations of the heterozygous from the mean, dominance effect), was sufficient to explain all variation observed. The estimates of the coefficient of determination $\left(\mathrm{R}^{2}\right)$ were higher than $99 \%$ (Table 1), indicating, as above mentioned, a well-fitting model. No report of mean component estimates was found for traits associated to pathogen resistance, using grade scales in common bean. However, there are reports of mean components estimated for resistance to Phakopsora pachyrhizi (Asian rust) in soybean (Ribeiro et al., 2007). In most cases these authors also found a well-fitting model with only $m, a$ and $d$, that is, without epistasis. It is important to mention that these authors used a $0 \%$ to $100 \%$ disease severity grade scale for leaves.

The estimates of $m, a$ and $d$ of the crosses involving the parents contrasting for resistance showed that these values were very similar. The $m$ estimate, for example, varied from 4.57 (cross Carioca $\mathrm{MG} \times \mathrm{Ca}-$ rioca) to 4.92 (Carioca $\mathrm{MG} \times \mathrm{CNFC} 10443$ ). The errors associated to the $m$ estimate were also of small magnitude, with values below $10 \%$ of the estimate in all cases (Table 1).

In general, the same observations as for $m$ are valid for the estimate of $a$, i.e., of the additive effect. They were also similar for the crosses, although the error variation associated to estimate $a$ was greater. Even then the associated error may also be considered small (below 20\% in all cases).

The estimated contribution of the loci in heterozygosis, presence of dominance $(d)$, were also similar to the $(a)$ estimates (Table 1). The average level of dominance varied from 0.61 (cross ESAL $583 \mathrm{u}$ Uirapuru) to 1.01 (ESAL $566 \times$ Esal 522), indicating dominance in the trait control (Cruz et al., 2004). Since the estimate of $d$ was negative, it was inferred that the dominance is in the sense of conferring resistance, since, by the criterion of grade scales, plants with less symptoms have lower grades.
For some crosses where the $\mathrm{F}_{3}$ generation was available, the components of genetic and phenotypic variance were estimated (Table 2). In all cases, the model fit well, with $\mathrm{R}^{2}$ higher than 0.92 . The estimated additive variance $\left(\hat{\sigma}_{A}^{2}\right)$ was similar in the crosses: $\hat{\sigma}_{A}^{2}$ $=4.72$ in cross Carioca $\mathrm{MG} \times$ Carioca and $\hat{\sigma}_{A}^{2}=5.69$ for Carioca $\mathrm{MG} \times$ Uirapuru. The confidence interval (CI) was of small magnitude and the lower limit of the range was always positive, indicating that $\hat{\sigma}_{A}^{2}$ differed from zero.

The estimated dominance variance $\left(\hat{\sigma}_{D}^{2}\right)$ for cross Carioca MG $\times$ Carioca was nearly twice as high as $\hat{\sigma}_{A}^{2}$. In the cross Carioca MG u Uirapuru the $\hat{\sigma}_{D}^{2}$ value was similar to $\hat{\sigma}_{A}^{2}$. The CI of $\hat{\sigma}_{D}^{2}$ was also of small magnitude and the lower limit positive, indicating that $\hat{\sigma}_{D}^{2}$ differed from zero.

The estimates of environmental variance $\left(\hat{\sigma}_{E}^{2}\right)$ were lower than the component of genetic variance, allowing the conclusion that the environmental influence on the trait is small. It is important to mention that the plants to be inoculated were rigorously controlled, in the system of inoculation and post-inoculation, and that the plant development in the pots occurred under controlled environmental conditions.

The estimated average degree of dominance was, in all cases, higher than that obtained by the mean component. The estimates of the component of variance are normally associated to a more pronounced error than the mean component (Bernardo, 2002). This is most likely the reason why the estimates of average degree of dominance, especially in the cross Carioca MG u Carioca, were higher than 1.0. However, as stated above for the mean components, dominance may be inferred in the trait control.

The heritability estimates in the narrow sense $\left(\hat{h}_{n}^{2}\right)$ were higher than $34 \%$ (Table 2). Considering that the evaluation was performed in plants, this heritability can be considered of mean magnitude. Unfortunately, no report was found of $\hat{h}_{n}^{2}$ estimate in plants in the pathosystem Fusarium oxysporum f. sp. phaseoli - common

Table 1 - Estimated mean components for the trait severity grades of Fusarium oxysporum $\mathrm{f}$. sp. phaseoli, the standard error associated to each estimate, average level of dominance and the coefficient of determination $\left(\mathrm{R}^{2}\right)$.

\begin{tabular}{|c|c|c|c|c|c|}
\hline \multirow{2}{*}{ Cross } & \multicolumn{3}{|c|}{ Component of mean \pm standard error } & \multirow{2}{*}{$\begin{array}{c}\text { Average level of } \\
\text { dominance }\end{array}$} & \multirow{2}{*}{$\mathrm{R}$} \\
\hline & $\hat{m}$ & $\hat{a}$ & $\hat{d}$ & & \\
\hline Carioca MG $\times$ Carioca & $4.57^{1} \pm 0.36$ & $-4.00^{1} \pm 0.83$ & $-3.12^{1} \pm 0.53$ & 0.78 & 0.99 \\
\hline Carioca MG $\times$ Uirapuru & $4.69^{1} \pm 0.04$ & $-3.58^{1} \pm 0.08$ & $-2.54^{1} \pm 0.09$ & 0.71 & 0.99 \\
\hline Carioca MG $\times$ CNFC 10443 & $4.92^{1} \pm 0.46$ & $-3.53^{2} \pm 0.56$ & $-3.17^{\mathrm{NS}} \pm 0.73$ & 0.90 & 0.99 \\
\hline Esal $583 \times$ CNFC 10443 & $4.76^{1} \pm 0.33$ & $-3.20^{2} \pm 0.41$ & $-3.00^{2} \pm 0.48$ & 0.93 & 0.99 \\
\hline Esal $583 \times$ Uirapuru & $4.83^{1} \pm 0.32$ & $-3.55^{2} \pm 0.39$ & $-2.71^{2} \pm 0.48$ & 0.61 & 0.99 \\
\hline Esal $566 \times$ Esal 522 & $4.88^{1} \pm 0.42$ & $-2.97^{2} \pm 0.47$ & $-3.00^{2} \pm 0.55$ & 1.01 & 0.99 \\
\hline
\end{tabular}

${ }^{1 /}$ significant estimates by the $\mathrm{t}$ test at the $5 \%$ probability; ${ }^{2 /}$ significant estimates by the $\mathrm{t}$ test at the $10 \%$ probability; ${ }^{\mathrm{NS}}$ non-significant. 
Table 2 - Estimates of additive $\left(\hat{\sigma}_{A}^{2}\right)$, dominance $\left(\hat{\sigma}_{D}^{2}\right)$ and environmental $\left(\hat{\sigma}_{E}^{2}\right)$ variance, with its lower (LL) and upper (UL) limits, heritability in the narrow $\left(h_{r}^{2}\right)$ and broad sense $\left(h_{a}^{2}\right)$, coefficient of determination $\left(\mathrm{R}^{2}\right)$ and average level of dominance of the severity grades (1 a 9) of Fusarium oxysporum f. sp. phaseoli in crosses between common bean lines.

\begin{tabular}{lcc}
\hline \multirow{2}{*}{ Parameter } & \multicolumn{2}{c}{ Cross } \\
\cline { 2 - 3 } & $\begin{array}{c}\text { Carioca MG } \times \\
\text { Carioca }\end{array}$ & $\begin{array}{c}\text { Carioca MG } \times \\
\text { Uirapuru }\end{array}$ \\
\hline$\hat{\sigma}_{A}^{2}$ & 4.72 & 5.69 \\
$\mathrm{LL}$ & 4.00 & 4.85 \\
$\mathrm{UL}$ & 5.66 & 6.76 \\
$\hat{\sigma}_{D}^{2}$ & 8.77 & 4.62 \\
$\mathrm{LL}$ & 7.06 & 3.76 \\
$\mathrm{UL}$ & 11.18 & 5.82 \\
$\hat{\sigma}_{E}^{2}$ & 0.34 & 3.23 \\
$\mathrm{LL}$ & 0.19 & 1.95 \\
$\mathrm{UL}$ & 0.76 & 6.36 \\
$\hat{h}_{r}^{2}$ & 0.34 & 0.42 \\
$\hat{h}_{a}^{2}$ & 0.97 & 0.76 \\
$\mathrm{R}^{2}$ & 0.92 & 0.97 \\
Average level of & 1.93 & 1.27 \\
dominance &
\end{tabular}

bean in the literature. Higher heritability estimates for resistance to Fusarium wilt than observed here were obtained by Cross et al. (2000) $\left(\hat{h}_{n}^{2}=0.85\right)$. However, this estimate was obtained using the regression of the parent means and the mean of the $\mathrm{F}_{2}$ generation, involving the segregating populations $\left(\mathrm{F}_{2}\right)$, i.e., the estimate obtained by Cross et al. (2000) aims at the selection of populations rather than at $\mathrm{F}_{2}$ plants. In this case, the estimate is not directly comparable to the one obtained here. Estimates of heritability for resistance to other pathogens in common bean are frequent in the literature. Amaro et al. (2007) evaluated angular leaf spot (Pseudocercospora griseola) using $\mathrm{S}_{0: 1}$ progenies and obtained varying heritability estimates, from $21.8 \%$ to $70.5 \%$. Ribeiro et al. (2007) also studied the genetic control of Asian soybean rust (Phakopsora pachyrhizi), using percentage of disease severity. They estimated $h^{2}$ in the mean of the $F_{2: 3}$ progenies ranged from $42 \%$ to $74 \%$. In this case the values are not directly comparable either since the estimated mean was based on the progenies rather than on the plants.

The high heritability estimates in the broad sense in the plant ( $h_{b}^{2}$ above 0.76 ) (Table 2), together with the environmental control in the evaluations further suggest that few genes control the trait. Similar results were also reported by Cross et al. (2000), with race
4 of the fungus, in crosses involving lines originated from the Durango race. However, in lines of Mesoamerican origin similar to those used here, the authors evidenced the existence of polygene control of resistance. In contrast, Brick et al. (2004) stated that different genes are involved in the genetic control of races 4 and 5 of $F$. oxysporum f. sp. phaseoli and that the dominant allele is responsible for the resistance of both races.

\section{CONCLUSIONS}

The genetic control of resistance to Fusarium oxysporum f. sp. phaseoli involves genes with dominance, although additive effects are also expressive. Heritability is high, showing that selection should be easy, since efficient inoculation and selection methods are used.

\section{ACKNOWLEDGEMENTS}

To Fundação de Amparo à Pesquisa do Estado de Minas Gerais (Fapemig) for a doctorate grant and to Conselho Nacional de Desenvolvimento Científico e Tecnológico $(\mathrm{CNPq})$ for financial support.

\section{REFERENCES}

ALVES-SANTOS, F.M.; CORDEIRO-RODRIGUES, L.; SAYAGUÉS, J.M.; MARTÍN-DOMINGUEZ, R.; GARCÍA-BENAVIDES, P.; DÍAZ-MÍNGUEZ, J. M.; ESLAVA, A.P. Pathogenicity and race characterization of Fusarium oxysporum f. sp. phaseoli isolates from Spain and Greece. Plant Pathology, v.51, p.605-611, 2002.

AMARO, G.B.; ABREU, A.F.B.; RAMALHO, M.A.P.; SILVA, F.B. Phenotypic recurrent selection in the common bean (Phaseolus vulgaris L.) with carioca-type grains for resistance to the fungi Phaeoisariopsis griseola. Genetics and Molecular Biology, v.30, p.584-588, 2007.

BRICK, M.A.; OGG, J.B.; SCHWARTZ, H.F.; BYRNE, P.F.; KELLY, J.D. Resistance to multiple races of Fusarium oxysporum f. sp. phaseoli en common bean. Annual Report of the Bean Improvement Cooperative, v.47, p.131-132, 2004.

BURUCHARA, R.A.; CAMACHO, L. Common bean reaction to Fusarium oxysporum f. sp. phaseoli, the cause of severe vascular wilt in Central Africa. Journal of Phytopathology, v.148, p.39-45, 2000.

CROSS, H.; BRICK, M.A.; SCHWARTZ, H.F.; PANELLA, L.W.; BYRNE, P.F. Inheritance of resistance to fusarium wilt in two common beans races. Crop Science, v.40, p.954-958, 2000.

CRUZ, C.D.; REGAZZI, A.J.; CARnEIRO, P.C.S. Modelos biométricos aplicados ao melhoramento genético. 3 ed. Viçosa: UFV, 2004. v.1, 480p.

ELENA, K.; PAPAS, A.C. Pathogenicity and vegetative compatibility of Fusarium oxysporum f.sp. phaseoli in Greece. Journal of Phytopathology, v.150, p.495-499, 2002.

FERREIRA, D.F.; ZAMBALDE, A.L. Simplificação de algumas técnicas especiais da experimentação agropecuária no Mapgen e softwares correlatos. In: CONGRESSO DA SOCIEDADE BRASILEIRA DE INFORMÁTICA APLICADA A AGROPECUÁRIA E AGROINDÚSTRIA, 1., 1997, Belo Horizonte. Anais. Belo Horizonte, 1997. p.285-281. 
PASTOR-CORRALES, M.A.; ABAWI, G.S. Reactions of selected bean germplasms to infection by Fusarium oxysporum f. sp. phaseoli. Plant Disease, v.71, p.990-993, 1987.

PEREIRA, M.J.Z.; RAMALHO, M.A.P.; ABREU, A.F.B. Estratégias para eficiência da seleção de feijoeiro quanto à resistência à murcha-de-fusarium. Pesquisa Agropecuária Brasileira, v.23, p.721-728, 2008.

RIBEIRO, R.L.D.; HAGEDORN, D.J. Inheritance and nature of resistance in beans to Fusarium oxysporum f. sp. phaseoli. Phytopathology, v.69, p.859-861, 1979.

RIBEIRO, A.S.; MOREIRA, J.U.V.; PIEROZZI, P.H.B.; RACHID, B.F.; TOLEDO, J. F.F.; ARIAS, C.A.A.; SOARES, R.M.; GODOY, C.V. Genetic control of Asian rust in soybean. Euphytica, v.157, p.15-25, 2007.

SALA, G.M.; ITO, M.F.; CARBONELL, S.A.M. Reação de genótipos de feijoeiro comum a quatro raças de Fusarium oxysporum f. sp. phaseoli. Summa Phytopathologica, v.32, p.286-287, 2006.
SALGADO, M.O.; SCHWARTZ, H.F. Physiological specialization end effects of inoculum concentration on Fusarium oxysporum f. sp. phaseoli in common beans. Plant Disease, v.79, p. 492496, 1993.

SALGADO, M.O.; SCHWARTZ, H.F.; BRICK, M.A. Inheritance of resistance to a Colorado race of Fusarium oxysporum f. sp. phaseoli in common beans. Plant Disease, v.79, p.279-281, 1995.

WOO, S.L.; ZOINA, A.; DEL SORBO, G.; LORITO, M.; NANNI, B.; SCALA, F.; NOVIELLO, C. Characterization of Fusarium oxysporum f. sp. phaseoli by pathogenic races, VCGs, RFLPs, and RAPD. Phytopathology, v.86, p.966-973, 1996.

Received July 18, 2008

Accepted May 19, 2009 